\title{
Altered hyaluronic acid content in tear fluid of patients with adenoviral conjunctivitis
}

\author{
JULIANA L. DREYFUSS ${ }^{1,2^{*}}$, CAIO V. REGATIERI ${ }^{1,3,5^{*}}$, BRUNO COELHO ${ }^{1}$, JOSÉ B. BARBOSA $^{3}$, \\ DENISE DE FREITAS ${ }^{3}$, HELENA B. NADER ${ }^{1}$ and JOÃO R. MARTINS ${ }^{1,4}$

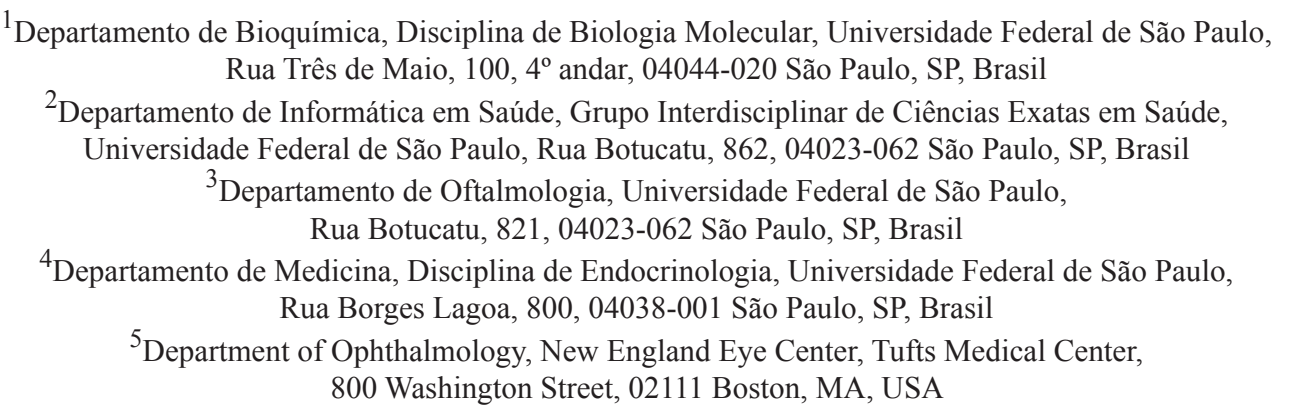

Manuscript received on March 13, 2014; accepted for publication on October 24, 2014

\begin{abstract}
The adenoviral conjunctivitis is one of the biggest causes of conjunctival infection in the world. Conjunctivitis causes relatively nonspecific symptoms, as hyperaemia and chemosis. Even after biomicroscopy, complex laboratory tests, such as viral culture, are necessary to identify the pathogen or its etiology. To contribute to the better understanding of the pathobiology of the adenoviral conjunctivitis, the tear fluids of patients with unilateral acute adenovirus conjunctivitis (UAAC), normal donors (control) and patients with allergic conjunctivitis were analyzed. Tear samples were collected with Schirmer strips from control, allergic conjunctivitis and UAAC patients, diagnosed by clinical signs. UAAC tears were tested positive in viral cultures. After the elution, HA was quantified using an ELISA-like fluorometric assay and the protein profile was determined by SDS-PAGE. A profound increase in the HA tear content in UAAC patients was found when compared to control and ALC. This HA increase in UAAC tears remarkably was not observed in tears from contralateral eyes without clinical signs, nor in allergic conjunctivitis. In addition a distinct profile of UAAC tear proteins was observed in patients with UAAC. The quantification of HA in the tear fluid is a rapid, sensitive and specific test. This molecule might be a biomarker candidate for acute conjunctivitis.
\end{abstract}

Key words: conjunctivitis, glycosaminoglycans, hyaluronic acid, tear film.

\section{INTRODUCTION}

The adenovirus conjunctivitis is one of the most common conjunctival infection. Normally it does not

Correspondence to: Juliana L. Dreyfuss

E-mail: jdreyfuss@unifesp.br

*Both authors contributed equally to this work result in vision loss, but it frequently causes abstention from school or work, with a high economic and social cost (Okada and Forrester 2000, Butt and Chodosh 2006). Although its pathogenesis is not completely understood, the role of extracellular matrix components has recently been studied (Natividad et al. 2006). 
A healthy ocular surface requires a functional tear film. The normal function of tear fluid is due to its complex biochemical composition consisting of buffered electrolytes and a diversity of proteins and glycoconjugates (Van Haeringen 1981, Baker et al. 2006).

Hyaluronic acid (HA), an important component of the extracellular matrix, is a large glycosaminoglycan composed of repeating units of $\beta$ - $D$-glucuronic acid and $N$-acetyl- $D$-glucosamine. HA plays an important role in tissue development, cell migration, cell proliferation and inflammation (Inoue and Katakami 1993, Gomes et al. 2004). $\mathrm{HA}$ is increased in the tear fluid when corneal epithelium erosion is present, and may play an important role in corneal epithelium wound healing (Oya et al. 1995, Miyauchi et al. 1996). Tear fluid consistency (gel-like) can be attributed to HA (Itano et al. 1999). Another important characteristic of this GAG is its chemical structure that can attract ions and water due to a negative charge density (Frescura et al. 1994, Yoshida et al. 1996).

Endogenous hyaluronan is present in virtually all corneal disorders (Fitzsimmons et al. 1994). HA is normally detected only in the corneal endothelium, and the presence of any amount of this compound in the epithelium or stroma is likely to indicate altered tissue (Inoue and Katakami 1993). Vitreous humor contains HA and its receptor (CD44), and these molecules are also present at the apical surface of corneal endothelium (Tengblad 1979).

Tear proteins also play an important role in maintaining eye surface integrity and in patients with external eye diseases (Avisar et al. 1981, Van Haeringen 1981, Ballow et al. 1987). The protein fraction of normal tears contains antimicrobial factors which are important for protecting the external eye from infection. These substances are produced by the main and accessory lacrimal glands. Important components of the hosts defense system for the external eye include complement proteins, immunoglobulins, especially secretory $\operatorname{IgA}$ (sIgA), lysozyme, lipocalin (TSPA) and lactoferrin (Friedman 1990, Kuizenga et al. 1991, Tragoulias et al. 2005). Lactoferrin, an iron complexing protein in normal tears, has bacteriostatic, bactericidal and complement $(\mathrm{C})$ inhibitory activity properties which make this tear protein an important component of the nonspecific host defense system of the external eye (Ballow et al. 1987, Flanagan and Willcox 2009). Human tear prealbumin, now called tear lipocalin, was described as a major protein in tear fluid, and is the main lipid binding protein in tears. It exerts important functions in eyelid lubrification, and acting as a general protection factor for cornea and conjunctiva epithelia (Redl 2000). IgA is the only significant immunoglobulin found in tear film. The antibodies are postulated to play a role in preventing adherence of microorganisms to the ocular surface (Alizadeh et al. 2001, Knop and Knop 2005). Another component of tears is lysozyme, a bacteriolytic protein first described by Fleming (Fleming 1922, McClellan 1997, Caffery et al. 2008). An allergen exposure can cause a marked increase in lysozyme secretion (Proud et al. 1998).

The aim of this study was to quantify HA content and verify the protein profile of tear fluids from patients with adenoviral conjunctivitis and compare them with normal donors.

\section{MATERIALS AND METHODS}

SUBJECTS

Tear samples were obtained from 53 patients; 15 eyes affected by acute adenoviral conjunctivitis, diagnosed from clinical signs, without epithelial defects and testing positive for viral culture and 15 contralateral eyes without clinical signs; as well as both eyes from 23 normal subjects as controls (total 46 control eyes). Tears from 15 patients affected by allergic conjunctivitis (total 26 allergic conjunctivitis eyes) were also analyzed. Patients with systemic diseases (rheumatoid arthritis, liver diseases and cancer) that could alter the concentration of secreted HA were excluded from the study. The characteristics of the subjects are shown in Table I. The patients with unilateral acute adenovirus conjunctivitis (UAAC) 
TABLE I

Patients and donors characteristics.

\begin{tabular}{cccc}
\hline & $\begin{array}{c}\text { Patients } \\
\text { UAAC }\end{array}$ & $\begin{array}{c}\text { Patients } \\
\text { ALC }\end{array}$ & $\begin{array}{c}\text { Donors } \\
\text { (both eyes) }\end{array}$ \\
\hline No. & 15 & 15 & 23 \\
Age (mean \pm SD) & $32.6 \pm 14.7$ & $11.8 \pm 3.72$ & $25.2 \pm 3.02$ \\
Sex & & & \\
F & 9 & 4 & 15 \\
M & 6 & 11 & 8 \\
\hline
\end{tabular}

UAAC, unilateral acute adenovirus conjunctivitis; ALC, allergic conjunctivitis; F, female; M, male. Table shows standard errors for patients age.

presented all of the following signs and symptoms: conjunctival hyperemia, ocular secretion, no corneal epithelium erosion, conjunctival follicular reaction, no use of any ocular medication and symptoms that had started for no more than 3 days prior. In the contralateral eye group, we included contralateral eyes from patients with UAAC that didn't have any clinical signs of acute conjunctivitis. Diagnosis of allergic conjunctivitis was based on clinical history and evaluation of signs and symptoms. Patients included in the study were in an active inflammatory phase of the disease with active limbal infiltrates and were free of topical antihistamines and mast cell stabilizers for at least 3 days, topical corticosteroids for at least 7 days, and systemic antiallergic treatment for at least 2 week at the time of first presentations. The control group constituted of patients without any ocular or systemic diseases.

The ethics Committee of the Federal University of São Paulo approved this protocol and a written informed consent was obtained from each subject. The study protocol adhered to the tenets of The Declaration of Helsinki.

\section{SAMPLE COLLECTION}

For collecting the tears, Schirmer strips were placed in the temporal side of each eyeunder the eyelid, during 5 minutes, without any use of topical anesthetics. The strips were dried at room temperature and stored at $-20^{\circ} \mathrm{C}$ until analysis. The same procedure was performed for the three groups.

\section{ADENOVIRAL CUlture}

At the same time, conjunctival swabs were collected in the affected eye group in medium appropriate for adenoviral culture, using Hep-2 cells as described by de Paiva et al. 1992.

\section{TEAR SAMPLE PREPARATION}

Tear compounds were eluted from the Schirmer strips using $100 \mu \mathrm{L}$ of distilled water, and HA and protein content analyses were performed.

\section{HA MEASUREMENT}

HA content in tear fluids was assayed by a noncompetitive and non-isotopic fluoroassay (Martins et al. 2003). Eluted tear fluids and standard concentrations of HA (Sigma, St. Louis, MO) were added to 96 multiwell plates (FluoroNUNC Maxisorp-microtiterplates, Roskilde, Denmark) previously coated with HA-binding protein. The plates were then sequencially incubated with biotinylated HA-binding protein and europiumlabeled streptavidin (Amershan, Piscataway, NJ). Afterwards, the europium remaining in the solid phase was released by an enhancement solution and the fluorescence was measured using a time-resolved fluorometer (Perkin-Elmer Life Sciences-Wallac Oy, Turku, Finland). The data (counts/s) were processed automatically using the MultiCalc software program (Perkin-Elmer Life Sciences-Wallac Oy) and values are expressed as ng/mg protein.

\section{PROTEIN ANALYSIS}

Total tear protein concentration was determined using a colorimetric assay kit according to the manufacturer's instructions (Protein Assay Kit from Bio-Rad, Hercules, CA). The protein profile was analyzed through sodium dodecylsulfate polyacrylamide gel electrophoresis (SDS-PAGE) as previously described (Laemmli 1970). Briefly, $10 \mu \mathrm{g}$ of protein from the tear samples were applied to a $3-20 \%$ linear gradient polyacrylamide gel under reducing conditions. After electrophoresis, 
the gels were stained by comassie blue (Bio-Rad, Hercules, CA). Each protein band was quantified by densitometry using the software ImageJ Version 10.2 for Mac (U.S. National Institutes of Health, Bethesda, Maryland, USA). The results are expressed by arbitrary densitometric units (ADU).

STATISTICAL ANALYSIS

Data are expressed as mean \pm standard error of the mean. Statistical analyses were performed using One-way ANOVA with Bonferroni's Multiple Comparison test, using Graph Pad Prism 5.0 software for Mac. A 95\% confidence interval and a 5\% level of significance were adopted; therefore, results with $P$-value less than or equal to 0.05 were considered significant.

\section{RESULTS}

COMParison of Hyaluronic ACID CONTENT In TEAR Fluid FROM PATIENTS AFFECTED BY CONJUNCTIVITIS AND NORMAL DONORS

The HA content in tears from eyes with UAAC $(n=15)$, from contralateral eyes $(n=15)$, from eyes of normal donors $(n=46)$ and from allergic conjunctivitis $(\mathrm{n}=26)$ was: $102.9 \pm 19.9 \mathrm{ng} /$ $\mathrm{mg}$ protein; $51.02 \pm 8.5 \mathrm{ng} / \mathrm{mg}$ protein, $25.2 \pm$ $2.3 \mathrm{ng} / \mathrm{mg}$ protein and $35.5 \pm 4.5 \mathrm{ng} / \mathrm{mg}$ protein, respectively. The comparison of HA content among the three groups showed a significant difference $(P<0.0001)$ (Fig. 1). UAAC tears presented higher HA concentrations when compared to either normal tears $(P<0.0001)$, tears from contralateral eyes or tears from allergic conjunctivitis. HA content in tears from contralateral eyes did not differ $(\mathrm{P}>0.05)$ from tears from normal donors or from tears from patients affected by allergic conjunctivitis.

\section{PROTEIN CONTENT AND QUALITATIVE ANALYSIS OF TEARS}

The protein analysis showed distinct protein profiles when comparing tears from UAAC eyes to tears from contralateral eyes. Polypeptide bands were identified by matching their migrations

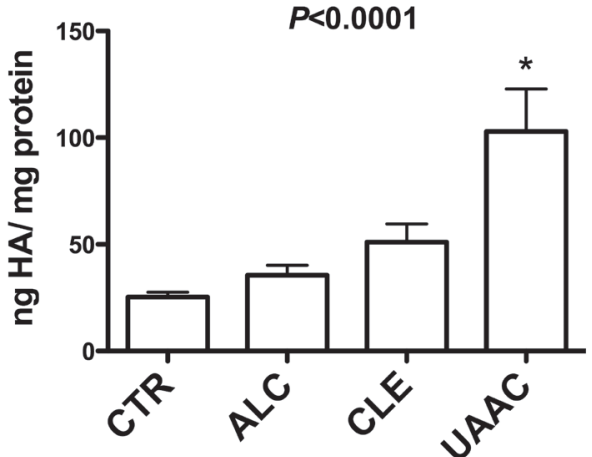

Figure 1 - Hyaluronic acid content in tear fluid of UAAC patients, normal donors and allergic conjunctivitis. HA was measured in tears by a non-competitive fluorometric ELISAlike assay. The HA content in tears of all UAAC eyes, in the contralateral eyes (CLE), in eyes of normal donors (CTR) and allergic conjunctivitis (ALC) was $102.9 \pm 19.9 \mathrm{ng} / \mathrm{mg}$ protein; $51.02 \pm 8.5 \mathrm{ng} / \mathrm{mg}$ protein; $25.2 \pm 2.3 \mathrm{ng} / \mathrm{mg}$ protein and $35.5 \pm 4.5 \mathrm{ng} / \mathrm{mg}$ protein respectively. The statistical analysis was performed using ANOVA followed by Bonferroni's post test. Abbreviations: UAAC, unilateral acute adenoviral conjunctivitis; CLE, contralateral non-affected eye; ALC, Allergic conjunctivitis.

to those of molecular weight standards. Tear protein patterns from normal donors have been exhaustively reported by previous investigators (Ballow et al. 1987, Lopez-Cisternas et al. 2006, Mann and Tighe $2007)$ and are represented by lactoferrin $(79 \mathrm{kDa})$, sIgA-heavy chain (66 kDa), sIgA-light chain (27 kDa), lipocalin (TSPA, $18 \mathrm{kDa})$, and lysozyme (14 kDa) (Fig. 2). Figure 3 shows that eyes affected by UAAC presented higher amounts of sIgA-heavy chain when compared to the contralateral eyes (CLE) or allergic conjunctivitis (ALC) $(P=0.0368)$. On the other hand, UAAC presented lower quantities of lipocalin or TSPA $(P=0.0394)$ and lactoferrin $(P=0.0018)$ when compared to CLE. No differences were found in the protein content of sIgA-light chain among UAAC, CLE and ALC. Finally, lysozyme is increased in tears from ALC compared to UAAC or CLE $(P<0.0001)$.

\section{DISCUSSION}

We show that UAAC leads to a significant increase in tear HA content. The difference found between 
HA tear content in UAAC was 2 times greater than that from contralateral eyes without clinical signs and 4 times higher than in the tears from normal donors indicating that HA could be a marker for subclinical inflammation. HA levels in tears of patients affected by allergic conjunctivitis showed no differences compared to tears from normal subjects.

Our results show that the levels of HA content in the tear fluid are related to the viral injury and conjuctival inflammation, suggesting that higher levels lead to a situation in which the viscoelastic properties of HA may protect corneal epithelium and help promote wound healing (Laurent and Fraser 1992, Miyauchi et al. 1996).

We may also consider that HA may be playing an important role in promoting inflammatory cell migration to the conjunctiva, possibly modulating inflammatory cytokine release (Mummert 2005).

UAAC, CLE and ALC tear protein profiles showed 79, 66, 27, 24, 18, and $14 \mathrm{kDa}$ bands, which were a constant feature with different amounts of each protein (Fig. 2). The protein profile of tears is well established in normal eye (Kuizenga et al. 1991). In accordance to the data reported by other authors (Janssen and Van Bijsterveld 1981, Kuizenga et al. 1991), we propose that the proteins observed in the present study correspond to lactoferrin $(79 \mathrm{kDa})$, sIgA-heavy chain $(66 \mathrm{kDa})$, sIgA-light chain (27 kDa), lipocalin (TSPA, $18 \mathrm{kDa}$ ), and lysozyme $(14 \mathrm{kDa})$, respectively.

A higher content of SIgA was found in UAAC, when compared to CLE. Secretory IgA-enriched fluid presumably augments the effectiveness of the external barrier to microbial adherence and increases the efficiency by which pathogens are processed by the immune and inflammatory systems (Sack et al. 1992). No differences were found in sIgA light chain content.

The decrease in lactoferrin and lipocalin levels in UAAC tears may occur evoked by major reflex tearing caused by inflammation (de Paiva et al. 1992). Furthermore, lactoferrin has been shown to

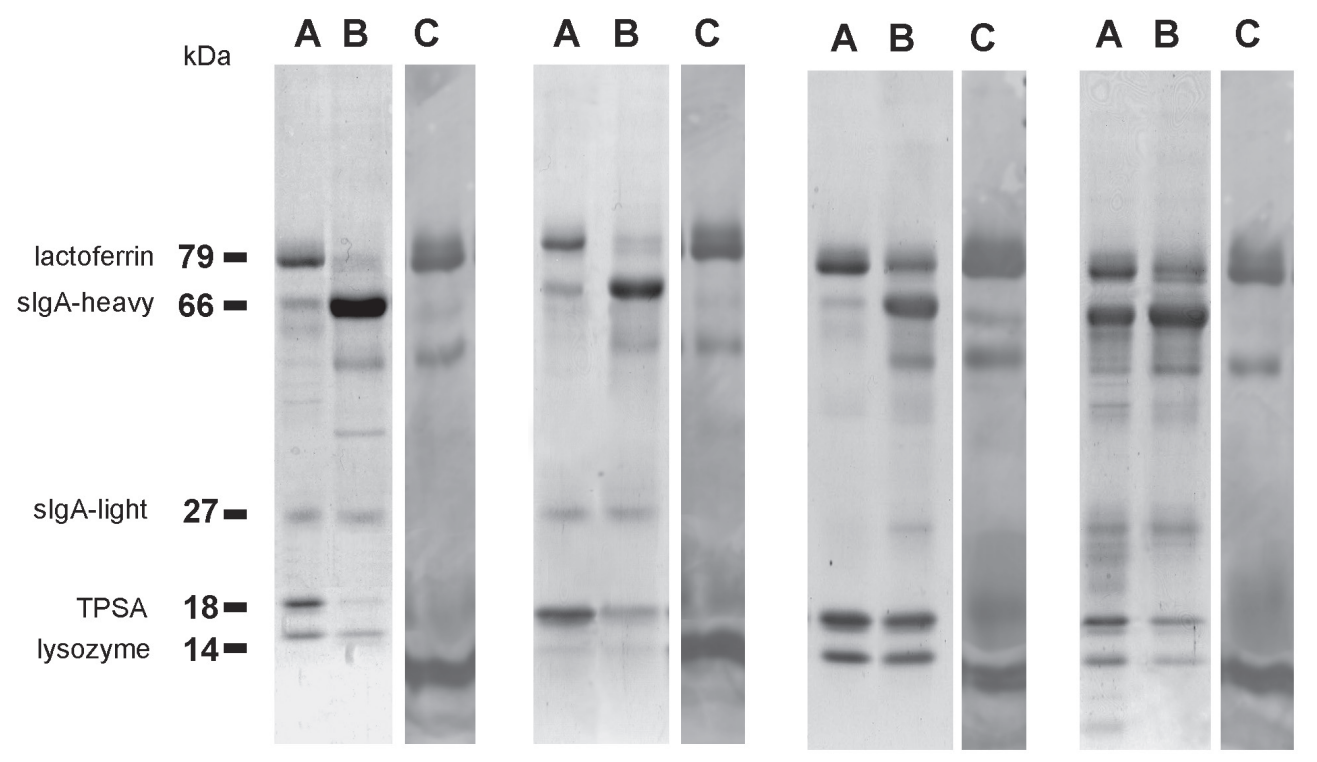

Figure 2 - Protein profile in tear of allergic and adenoviral conjunctivitis. Electrophoretic profiles of human tear fluid on SDS-PAGE revealed by Coomassie blue staining. In A (contralateral eye), B (acute adenoviral conjunctivitis eye) and $\mathbf{C}$ (allergic conjunctivitis), the corresponding profiles of 4 different subjects are shown. Protein bands were identified by matching their migrations to those of molecular weight standards; lactoferrin (79 kDa), serum albumin and sIgA-heavy chain (66 kDa), sIgA-light chain (27 kDa), lipocalin (TPSA, $18 \mathrm{kDa})$, and lysozyme (14 kDa). 


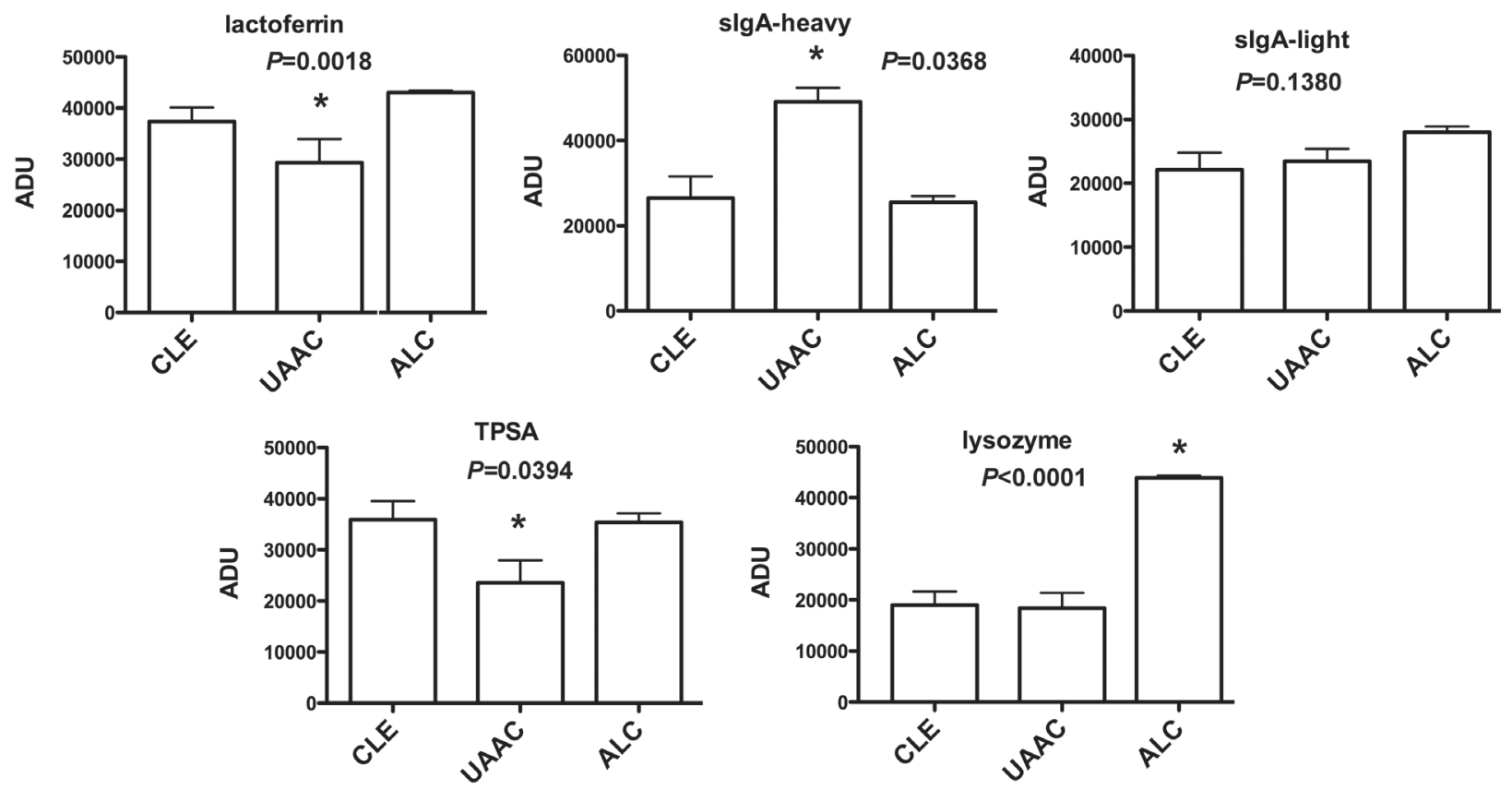

Figure 3 - Protein quantification in tear of allergic and adenoviral conjunctivitis. Protein bands of human tear fluid on SDS-PAGE were quantified by densitometry: lactoferrin $(79 \mathrm{kDa})$, serum albumin and sIgA-heavy chain (66 kDa), sIgA-light chain (27 kDa), lipocalin (TPSA, $18 \mathrm{kDa}$ ), and lysozyme $(14 \mathrm{kDa})$. The results are expressed by arbitrary densitometric units (ADU). Statistical analyses were performed by one way ANOVA and Bonferroni's post test. Abbreviations: CLE, contralateral non-affected eye; UAAC, unilateral acute adenoviral conjunctivitis eye; ALC, allergic conjunctivitis.

possess antiviral activity against adenovirus. This possible down regulation may be an evolutionary mechanism used by adenovirus to survive in ocular tissue. There was no difference between UAAC and CLE regarding lysozyme secretion, but it was increased in ALC tears, since an allergen exposure can cause a marked increase in lysozyme secretion (Proud et al. 1998).

\section{CONCLUSIONS}

In this study we were able to identify an important increase in HA tear content in patients affected by UAAC, compared with normal donors or allergic conjunctivitis, using a rapid and non invasive method. Regarding protein analysis we could verify a distinct protein profile in tear fluid of UAAC patients. Taken together these results indicate that the increase in HA content seems to play a role in the tear fluid of UAAC patients. The quantification of HA in the tear fluid is a rapid, sensitive and specific test. This molecule might be a biomarker candidate for acute conjunctivitis.

\section{ACKNOWLEDGMENTS}

This work was supported by grants from Brazilian funding agencies Fundação de Amparo à Pesquisa do Estado de São Paulo (FAPESP), Conselho Nacional de Desenvolvimento Científico e Tecnológico (CNPq) and Coordenação de Aperfeiçoamento de Pessoal de Nível Superior (CAPES). We are indebted to Aline Mendes, M.Sc. for technical assistance, and to Vivien Jane Coulson-Thomas, Ph.D., for the English revision. Prof. Martins had full access to all the data in the study and takes responsibility for the integrity of the data and the accuracy of the data analysis.

ABBREVIATIONS

UAAC, unilateral acute adenovirus conjunctivitis; CLE, contralateral non-affected eye; ALC, allergic 
conjunctivitis; HA, hyaluronic acid; GAG, glyosaminoglycan; SDS-PAGE, sodium dodecylsulfate polyacrylamide gel electrophoresis.

\section{RESUMO}

A conjuntivite causada por adenovírus é uma das maiores causas de infecção da conjuntiva no mundo. A conjuntivite provoca sintomas relativamente inespecíficos, como hiperemia e quemose. Mesmo depois de biomicroscopia, testes laboratoriais complexos, como cultura viral, são necessários para identificar o patógeno ou sua etiologia. Para contribuir para o melhor entendimento da fisiopatologia da conjuntivite causada por adenovírus, lágrimas de pacientes com conjuntivite aguda unilateral causada por adenovírus (UAAC), de doadores normais (controle) e de pacientes com conjuntivite alérgica foram analisadas. As amostras foram coletadas com tiras de Schirmer de doadores normais, pacientes com conjuntivite alérgica e pacientes com UAAC diagnosticados por sinais clínicos e testes positivos em culturas virais. Após a eluição das lágrimas, o HA foi quantificado utilizando um ensaio fluorométrico semelhante ao ELISA e o perfil da proteína foi determinado por SDS-PAGE. Um aumento profundo no conteúdo de HA em lágrima de pacientes com UAAC foi encontrado quando comparado com o controle ou a conjuntivite alérgica. Este aumento de HA em lágrimas de pacientes com UAAC não foi observado em lágrimas do olho contralateral sem sinais clínicos ou de pacientes com conjuntivite alérgica. Além disso observou-se um perfil distinto de proteínas nas lágrimas de pacientes com UAAC. A quantificação de HA no fluido lacrimal é um ensaio rápido, sensível e específico. Esta molécula pode ser um bom candidato a biomarcador para conjuntivite aguda.

Palavras-chave: conjuntivite, glicosaminoglicanos, ácido hialurônico, lágrima.

\section{REFERENCES}

Alizadeh H, Apte S, El-Agha MS, Li L, Hurt M, Howard K, Cavanagh HD, McCulley JP AND Niederkorn JY. 2001. Tear $\operatorname{IgA}$ and serum $\operatorname{IgG}$ antibodies against Acanthamoeba in patients with Acanthamoeba keratitis. Cornea 20: 622-627.
AVISAR R, MENACHE R, SHAKEd P AND SAVIR H. 1981. Lysozyme content of tears in some external eye infections. Am J Ophthalmol 92: 555-558.

BAKER GR, MORTON M, RAJAPASKARS, BULLOCK M, GULLUS, MAZZI B AND LUDGATE M. 2006. Altered tear composition in smokers and patients with graves ophthalmopathy. Arch Ophthalmol 124: 1451-1456.

BALlow M, DONSHIK PC, RAPACZ P AND SAMARTINO L. 1987. Tear lactoferrin levels in patients with external inflammatory ocular disease. Invest Ophthalmol Vis Sci 28: 543-545.

ButT AL AND ChODOsh J. 2006. Adenoviral keratoconjunctivitis in a tertiary care eye clinic. Cornea 25: 199-202.

Caffery B, Joyce E, Boone A, Slomovic A, Simpson T, JONES L AND SENCHYNA M. 2008. Tear lipocalin and lysozyme in Sjogren and non-Sjogren dry eye. Optom Vis Sci 85: 661-667.

De Paiva TM, Takimoto S, Ishida MA, De Souza MC, ISHIMARU T, NEUMANN J AND KALIL J. 1992. Comparative study of adenoviruses with monoclonal antibodies. Rev Inst Med Trop Sao Paulo 34: 19-26.

Fitzsimmons TD, Molander N, SteneVi U, FAGerholm P, SCHENHOLM M AND VON MALMBORG A. 1994. Endogenous hyaluronan in corneal disease. Invest Ophthalmol Vis Sci 35: 2774-2782.

FLANAGAN JL and Willcox MD. 2009. Role of lactoferrin in the tear film. Biochimie 91: 35-43.

FLEMING A. 1922. On a Remarkable Bacteriolytic Element Found in Tissues and Secretions. Proceedings of the Royal Society of London. Series B, Containing Papers of a Biological Character 93: 306-317.

Frescura M, Berry M, Corfield A, Carrington S and Easty DL. 1994. Evidence of hyaluronan in human tears and secretions of conjunctival cultures. Biochem Soc Trans 22: $228 \mathrm{~S}$.

FRIEDMAN MG. 1990. Antibodies in human tears during and after infection. Surv Ophthalmol 35: 151-157.

Gomes JA, Amankwah R, POWELl-Richards A AND DUA HS. 2004. Sodium hyaluronate (hyaluronic acid) promotes migration of human corneal epithelial cells in vitro. $\mathrm{Br} \mathrm{J}$ Ophthalmol 88: 821-825.

INOUE M AND KATAKAMI C. 1993. The effect of hyaluronic acid on corneal epithelial cell proliferation. Invest Ophthalmol Vis Sci 34: 2313-2315.

ITANO N ET AL. 1999. Three isoforms of mammalian hyaluronan synthases have distinct enzymatic properties. J Biol Chem 274: 25085-25092.

JANSSEN PT AND VAN BIJSTERVELD OP. 1981. Comparison of electrophoretic techniques for the analysis of human tear fluid proteins. Clin Chim Acta 114: 207-218.

KNOP E AND KNOP N. 2005. The role of eye-associated lymphoid tissue in corneal immune protection. J Anat 206: 271-285.

Kuizenga A, VAn Haeringen NJ AND KiJlstra A. 1991. SDS-Minigel electrophoresis of human tears. Effect of sample treatment on protein patterns. Invest Ophthalmol Vis Sci 32: 381-386. 
LAEMMLI UK. 1970. Cleavage of structural proteins during the assembly of the head of bacteriophage T4. Nature 227: 680-685.

LAURENT TC AND FRASER JR. 1992. Hyaluronan. FASEB J 6: 2397-2404.

LOPEZ-CisTERNAS J, CASTILLO-DIAZ J, TRAIPE-CASTRO L AND LOPEZ-SOLIS RO. 2006. Use of polyurethane minisponges to collect human tear fluid. Cornea 25: 312-318.

MAnN AM AND TIGHE BJ. 2007. Tear analysis and lens-tear interactions. Part I. Protein fingerprinting with microfluidic technology. Cont Lens Anterior Eye 30: 163-173.

Martins JR, PASSERotTI CC, MACIEL RM, SAMPAiO LO, DIETRICH CP AND NADER HB. 2003. Practical determination of hyaluronan by a new noncompetitive fluorescencebased assay on serum of normal and cirrhotic patients. Anal Biochem 319: 65-72.

MCClEllan KA. 1997. Mucosal defense of the outer eye. Surv Ophthalmol 42: 233-246.

Miyauchi S, Morita M, Kuramoto K and Horie K. 1996. Hyaluronan and chondroitin sulfate in rabbit tears. Curr Eye Res 15: 131-135.

MUMMERT ME. 2005. Immunologic roles of hyaluronan. Immunol Res 31: 189-206.

Natividad A, CoOke G, Holland MJ, Burton MJ, Joof HM, ROCKETT K, KWIATKOWSKI DP, MABEY DC AND BAILEY RL. 2006. A coding polymorphism in matrix metalloproteinase 9 reduces risk of scarring sequelae of ocular Chlamydia trachomatis infection. BMC Med Genet 7: 40.

OKADA AA AND ForRESTER JV. 2000. Ocular inflammatory disease in the new millennium. Arch Ophthalmol 118 116-119.
Oya T, OBata H, Miyata K, TSURU T AND Miyauchi S. 1995. Quantitative analyses of glycosaminoglycans in tear fluids in normal human eyes and eyes with corneal epithelial disorders. Nippon Ganka Gakkai Zasshi 99: 302-307.

Proud D, REYNOLDS CJ, LiChTENSTEIN LM, KAGEYSOBOTKA A AND ToGIAS A. 1998. Intranasal salmeterol inhibits allergen-induced vascular permeability but not mast cell activation or cellular infiltration. Clin Exp Allergy 28: 868-875.

REDL B. 2000. Human tear lipocalin. Biochim Biophys Acta 1482: 241-248.

SACK RA, TAN KO AND TAN A. 1992. Diurnal tear cycle: evidence for a nocturnal inflammatory constitutive tear fluid. Invest Ophthalmol Vis Sci 33: 626-640.

TENGBLAD A. 1979. Affinity chromatography on immobilized hyaluronate and its application to the isolation of hyaluronate binding properties from cartilage. Biochim Biophys Acta 578: 281-289.

Tragoulias St, Anderton PJ, Dennis GR, Miano F And MiLlaR TJ. 2005. Surface pressure measurements of human tears and individual tear film components indicate that proteins are major contributors to the surface pressure. Cornea 24: 189-200.

VAN HAERINGEN NJ. 1981. Clinical biochemistry of tears. Surv Ophthalmol 26: 84-96.

YOSHIDA K, NITATORI Y AND UcHIYAMA Y. 1996. Localization of glycosaminoglycans and CD44 in the human lacrimal gland. Arch Histol Cytol 59: 505-513. 